\title{
Innovations Under the Concept of 'Turning Garbage into Gold' in Fisheries Waste Management
}

\section{Muhammad Yusuf*}

\begin{abstract}
This paper discusses the encouragement of creativity and innovation in creating opportunities for entrepreneurship turning useless materials into valuable resources. It is necessary to know the thought process and planning in the entrepreneurship idea to create a new business at this time. One of the brilliant philosophies about entrepreneurs is that they are those who can "turn garbage into gold". This concept describes the important character of entrepreneurs who foresee business opportunities and have the intelligence to transform trash into cash. This means that they have the necessary ability to create innovation and value-added products for sale. The analyzed case study involves innovation in using fisheries waste specifically derived from crab industries in Indonesia. The study presents empirical perspectives including (1) potential business of crab shell waste (2) technology in innovative use of shell to added value product (3) business analysis and commercialization. Ultimately, we present the concept of a new business by linking theories of entrepreneurial innovation and technology transfer in order to gain environmental balance.
\end{abstract}

Keywords: new entrepreneurship, innovation and creativity, Indonesia, fisheries waste, crab shell powder.

\section{Introduction}

Innovation is a tool or instrument used by entrepreneurs to exploit change as an opportunity (Drucker, 1985). Innovation may influence capabilities towards the commercialization (Foss et al., 2011). All innovation begins with creative ideas (Okpara, 2007). Today, the idea of innovation and entrepreneurship is used to encourage the emergence of change and in viewing opportunities around us. There are many ways to practice these concepts in turning new ideas into a business. One is the idea of utilizing resources that have become waste, so as to become value-added products.

\footnotetext{
* Muhammad Yusuf, Norwegian College of Fishery Science, The Arctic University of Norway, Brevika 9037, Troms $\varnothing$, Norway, muhammad.yusuf@uit.no.
} 
From idea to business; the implementation of business ideas, starting with the planning materials considered useless with regard to the potential availability of other supporting resources, furthermore, determines the appropriate new innovations to be integrated in the business plan. An especially important aspect to consider is whether there are useful substances available in the waste. The main determining factor is the market: does the business idea have a potential to be developed?

The business world is now beginning to embrace new thinking in which entrepreneurial activity is referred to as one of the factors required to achieve sustainable business growth and to become highly competitive. Entrepreneurship is based on creativity, and continuous innovation is necessary to survive (Baldacchino, 2009; Barringer and Ireland, 2006; Nystrom, 1993; Okpara, 2007; Witt, 2004). There is a need to provide new insights into the concept saying that "entrepreneurs are those who can turn garbage into gold"1. One of the places where there is still untapped resource potential is waste of fisheries resource, which could provide an opportunity for new entrepreneurs.

The study on waste innovation, technology and commercialization is an important foundation for entrepreneurs and government initiative to attract attention to environmental issues as well as social and economic benefits associated with waste management. The study focuses on the following:

- Identifying opportunities in waste utilization and emerging innovations.

- Identifying the market for the implementation of business.

- Identifying challenges, benefits, and implications in global perspective.

\section{Theory of entrepreneurship and innovations}

\section{Drive entrepreneurs - create something out of nothing}

Entrepreneurs are those who have the ability to see and evaluate business opportunities, collect the resources needed to take advantage of those opportunities and take the appropriate measures in order to ensure success (Meredith, Nelson and Neck, 1996). In another theory, entrepreneurship is the result of a process that applies creativity and innovation in a systematic and disciplined manner in order to meet the needs and capture opportunities in the market (Zimmerer and Scarborough, 1996). The role of the entrepreneur is to combine creative ideas with concerted action for business purposes. The characteristics of a successful entrepreneur include being able to complete

1 "Seeing a business opportunity where others do not and acting on it". Gibson, in a lecture conversation on 19th March 2013. Entrepreneurial opportunity discovery and exploitation were two integral parts of the entrepreneurial process (Shane, 2003; Fuduric, 2008 ). 
the process of creativity, then generate innovation, until the application can be deployed and break into the market with a profitable and sustainable business.

Creativity is a necessary feature of an entrepreneur (Henry, 2007). Creativity is the ability to make or bring into existence something new, such as new solutions and new methods. Wycoff (1991) defines creativity as something new which has a useful value. Creativity involves seeing things that everybody else has seen but that no one else has made. Creativity has a broad meaning, but in this case it is the concept of adding value to items that are not useful in order to sell them. In this context, entrepreneurial strategy involves focusing on new ideas and new views to create products with environmental benefits that are also profitable. In this modern era entrepreneurs compete to master the market by providing new added value to products that meet the needs of the market ${ }^{2}$. On the other hand, entrepreneurs also create competition by seeing more and different ways to create new products or services that have never been there ${ }^{3}$.

A philosophy which is emphasized here involves the foresight to read business opportunities, and the courage and mentality, as well as the capacity to produce and sell high-value-added performance, described as "turning garbage into gold or money". This is what is meant by the essence of entrepreneurship. It needs to be added to the concept that recognizing the importance of implementing a strong work ethic and leadership are the hallmarks of the modern businessman.

Every entrepreneur should have character and competence. The reason for the birth of every business is to solve a problem of market needs and create new added value for consumer satisfaction. Without the added value there is no customer satisfaction, and no customers; then a business will fail. The key idea is that an entrepreneur uses creativity and teamwork support.

\section{Open innovation and giving added value}

Humphreys, McAdam and Leckey (2005) assert that innovations require some supporting elements that are essential for their implementation and can improve the performance of the new venture. Some of these elements are: (1) leadership, (2) empowerment, (3) culture, (4) technology, (5) learning, (6) structure, and (7) management. The problem that arises is how to transfer the appropriate innovation to new businesses because they are often faced with the problems of the investment cost, technology support, lack of creativity and long procedure, therefore impact on their businesses declines. The next problem is how new businesses can improve their innovation capabilities,

2 Concept: create something new from something that already exists.

3 Concept: create something from nothing.

Journal of Entrepreneurship Management and Innovation (JEMI), Volume 9, Issue 4, 2013: 101-122 
because competition demands continuous consistency in innovating ${ }^{4}$. Moreover, starting a business by creating products from waste is risky. New businesses often run out of the power to be able to make innovations and are unable to compete.

Technological innovation opportunities can be found by doing research on the real possibilities of utilizing waste products. Using the appropriate technology in the waste processing business is not just the way the business team can benefit in terms of productivity, but also requires support technology that is able to adjust to the scope of work conditions. An awareness of the importance of innovation to new businesses requires the intervention of masterminds such as universities, research institutes, and companies. Technological innovation opportunities can still be created in order to get closer to the needs and culture of work. Technological innovation-oriented work culture can be an alternative solution to increasing business productivity. This can be done, for example, by making simple technological innovations in the operation of a device to make it simple in design and maintenance, as well as durable. However, not all innovation is technological as there should be consideration of the community role and households participation in waste recovery and reuse models.

Why innovate? Innovation is the successful exploitation of new ideas 5 . To be successful, entrepreneurs must know where and how their business will achieve its goal. This is why a clear concept of innovation is required for business needs to survive and thrive. Entrepreneurs need to adopt more effective operations and meet the realities of their intended market. Is there a high market demand for a product made from raw material waste? What innovations are needed? This can be answered with the appropriate methodological design innovation so they can understand the importance of innovation and how they do the innovation stages.

Why should we give added value to waste? The concept of value added can be interpreted as something that provides additional benefits, usefulness and also good quality during the process and in the final product (Fenoaltea, 1976). Waste generated by the industry can be processed into something more useful and is positive for the environment. In general, industry is less creative in managing waste. Waste minimization at source through the utilization of waste is achieved by looking at the benefits contained in the waste itself. Efforts in exploring this will reduce the volume of waste while also generating profits.

4 Innovation-orientation depends on the exploration of new possibilities through search and experimentation (MolinaCastillo and Munuera-Aleman, 2009).

5 Innovation defined as an idea, or object that is perceived as new by individual or other units of adoption like consumer and distributor groups (Rogers, 2003). 


\section{Entrepreneurship and transfer technology}

The gap between producers and users of technology has prompted various efforts to accelerate the rate of technology transfer from the laboratory to the market level. Collaborative efforts between the technology providers and users become an important factor. One of them is in environmental technology, especially the technology of waste treatment. Selection of waste treatment technology is essentially determined by the characteristics of the waste, which may be a result of processing value-added products. Selection of the technology to be used depends on the needs of the industry and the target market.

The success of technology transfer requires knowledge from various disciplines (Reisman, 1989). Transfer of technology has fairly broad definitions which comprise efforts to divert the understanding and skills of technology or knowledge developed within an organization to the other ${ }^{6}$. Nevertheless, the adoption of a technology does not necessarily create or result in growth and revenue performance in a business. Based on the premise that innovation and new technology play a role in the growth of a business, the entrepreneur is trying to put together a plan that encourages innovation with the assumption that the technology will become an integral part of its business growth. Government should therefore accelerate the transfer of technology, where technology and economic growth is one component of development (Melkers, et al, 1993).

With the use of modern technology, a product will grow to the point where it becomes more competitive. In order to win the competition, when marketing products, manufacturers must consider not only the quality of the product alone, but also the business strategy of market orientation (Jaworski and Kohli 1993; Narver and Slater, 1990), innovation (Foss et al., 2011; Rogers, 2003) ${ }^{7}$, and entrepreneurial orientation (Lumpkin and Dess, 1996, 2001; Weerawardena, 2003) ${ }^{8}$. To encourage entrepreneurial success in applying technology it is necessary to attempt to address gaps through presentation and use of research products and technologies. Effective mediation can connect two-way collaboration between research institutions and the business community as a user.

Why is technology so important? Technological orientation is viewed as an instrument of strategy, policy-oriented product development can be used with technology for management of the competition, with the assumption

\footnotetext{
6 Knowledge and technology transfer as an interactive process with a great deal of back-and-forth exchange among individuals over an extended period of time (Gibson and Smilor, 1991).

7 Adoption innovation concepts and taking innovation to the market.

8 Entrepreneurial orientation refers to the specific organizational-level behavior to perform risk-taking, self-directed activities, engaged in innovation and react proactively and aggressively to outperform the competitors in the marketplace (Lumpkin and Dess, 1996).
} 
that with the more advanced technology used, there will be increasingly innovative products produced and a greater chance of success. Advances in technology have been able to optimize achievement and support in entrepreneurship.

Entrepreneurs rely heavily on technology. The application of new technology is a decisive factor in the development of new products. Technological advantages in a product can attract consumers to buy it. Technology may accelerate new product development and create advantages (Li and Calantone, 1998).

\section{Methodology}

This study is to design a business framework for the identification of entrepreneurial opportunities through innovation. The goal is to analyze new entrepreneurship which creates innovation and is smart in addressing business environment. The primary data collecting for survey was conducted in Indonesia in crab industries, furthermore it was supported by secondary data for an overview of the potential marketing. The following steps of research including observations, experiments and descriptions were taken:

- Observation step is a series of surveys conducted to explore the potential of raw materials, process flow on crab industry and R\&D industry activities. It involved direct interviews with the employees and managers of crab factories in Indonesia.

- Experiment step is a technical test in processing crab waste conducted on laboratory scale in order to find beneficial substances. The purpose of the laboratory test is to observe the structure of shell powder and analyze the final product.

- Description step is an overview of the supporting factors including business planning, team building and commercialization strategies. The results described provide a factual overview of the benefits of crab waste and are further explained in the business concept.

The marketing data for organic waste products was collected from reports, trends and forecasts that have already been published through books, journals, news and internet sources. The marketing overview provides wider information to help identify business prospects and assess market potential. Marketing analysis can give a business a picture of what kinds of new products and services may bring a profit (Pyle, 2010). 


\section{Study innovations in organic waste management for business}

\section{Fisheries waste management}

Fisheries waste, is it a problem or does it have potential? Fishery development is progressing rapidly now, as well as manufacturing a product that can be used to meet food needs and create revenue sources, they also produce waste in the form of waste solids, liquids and gases. Until now these wastes have not generally been well managed and exploited, but have been thrown into the sea, rivers, lakes, beaches and other places. If it continues, this will disrupt sustainable development of the fishery sector in the future. This of course does not fit with the concept of environmentally sustainable development. In addition, such waste disposal practices can reduce the utility and value of fishery products, so it is very detrimental to the economy. The magnitude of the problem of waste management in the fisheries and aquaculture industry depends on the waste volume, its polluting charge, rate of discharge and the assimilatory capacity of the receiving medium (FAO, 2013).

Fisheries waste management has become a complex issue both technically and commercially. Of key importance in fisheries industries that produce organic waste is the focus on preventing the production of waste through waste minimization and reproduction of waste materials. In their business activities, fishery industries can be combined with the utilization of its waste materials byproduct. This course will give double the value added to society if they can manage it. Adding value to the management of waste in the fisheries industry could be a pattern that combines business processes as well as processing industry waste products in an economical way. These efforts can also be made by developing partnerships with new entrepreneurs by providing an incentive to treat waste. In these efforts, industry and new entrepreneurs should mutually benefit.

\section{A business potential by utilization of crab waste}

Creating innovation from crab waste into value added product aims to introduce ideas that can improve the environmental quality and open new business opportunities. There are several benefits from adding value to the crab waste, including: (1) the exploration of natural resources to product innovation (2) the use and transfer of technology (3) provision of economic value to the waste (4) open networking and marketing. 


\section{Potentials of Indonesian crab industries}

The Blue Swimming Crab (portunus pelagicus) or locally known as 'rajungan' is one of the most popular crab species in Indonesia'. Crab products are important fishery export commodities in Indonesia and need careful management attention regarding sustainability of the production chain and natural resource harvesting. Crabs commodities are abundant in Indonesia: 28 processing factories are active in processing this commodity, including canned, frozen and fresh crab products. Crab is important in commercial fisheries and catches have risen substantially. Landings of protunus pelagicus during 2001-2012 reached an average of 27.223 tons per year ${ }^{10}$.

The export of blue swimming crabs began in the mid-1990s due to increased demand from overseas, especially from importers in the United States of America. Before this, this commodity was only consumed locally, and had a very low price. Today, an estimated 95,000 fishermen and 17,000 pickers are involved in the crab business with either small or middle entrepreneurs (Sustainablefish, 2013). They work in over 400 tiny plants or cooking stations throughout Indonesia. Some are directly employed in the crab fishery. In addition, several thousand other people are involved in the fisheries, including middlemen, operators of tiny plants where initial processing is carried out and the final processors who export these products.

\section{Supply chains in the crab industry}

Almost $90 \%$ of the crabs processed in Indonesia are directed to markets in the United States (Yulianto, 2008). Most of the crab factories use pasteurization technology in their production, while only a few factories use sterilization technology. In general, the majority of their products are put in cans, but some are cup or pouch products. Recently some companies have begun intensive innovation with value-added products such as crab cakes and crab balls. Below is the supply and production chain in the crab industry:

\footnotetext{
9 Blue Swimming Crabs (Sp. Portunus Pelagicus) resources still rely on catching, while the aquaculture was intensely researched, See http://www.sustainablefish.org

10 Blue Swimming Crabs come from the tropical waters around Indonesia. One-day-fishing became their system of work and affected quality of the product, as fishermen actually catch and return back to their docks the same day, See http://www.fishsource.org.
} 


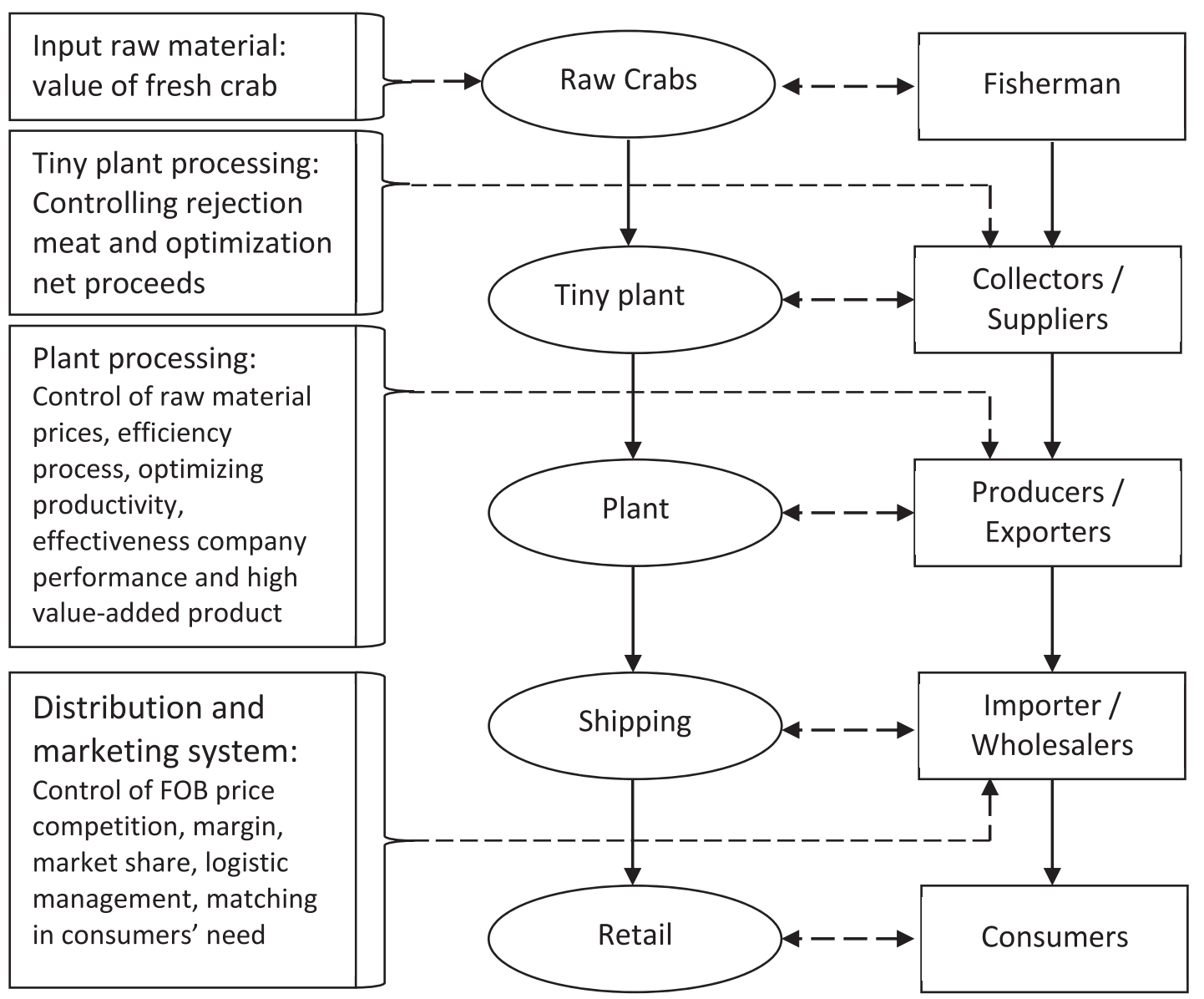

Figure 1. Supply chain of Indonesian Blue Swimming Crab

\section{Development of by-product from crab waste}

The blue swimming crab is one the main commodity exports of the Indonesian fisheries sector. There is a great deal of waste produced by the crab meat canning industry: shell waste makes up approximately $70-90 \%$ of the total weight of the meat. The large amount of crab shell waste is a serious problem that needs a solution.

The potential for development product related to substance content of crab shells which could be beneficial for supplemental food and feed. Crab shell waste contains substances that can be reused, including some highvalue products such as (1) natural supplements and cosmetic ingredients (2) animal feed additives (3) material spices. This waste could also be developed into a biological liquid extract as a feed additive for salmon that can produce colors which are brighter and fresher than those normally seen in aquaculture. There is thus potential for development in collaboration with the fish feed industry. 


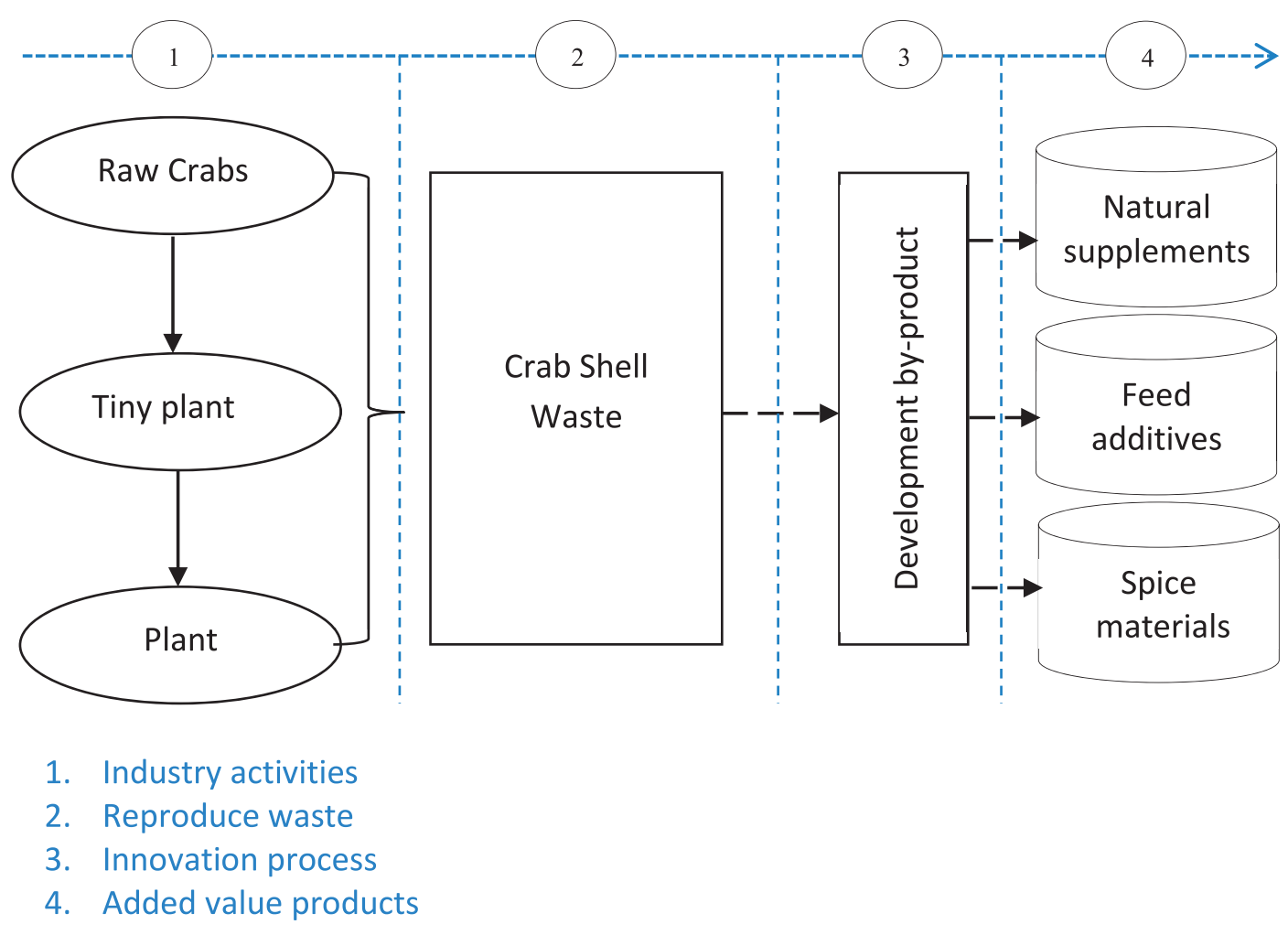

Figure 2. Product development of crab shell waste

One of popular by-products from crustacean commodity is chitosan product which forms a white to light-red solid powder. It is a deacetylated derivative from chitin, which is contained in abundance in crustacean shells i.e. crab, shrimp, lobsters and mushrooms. Commercial chitosan is commonly offered as powder or flakes. The chitosan capsule product is marketed as a dietary supplement for lose weight treatment. Crab shell extract is sold in stores in a pill form and is usually labeled as a fat attractor that expels fat from the body (Nutralegacy, 2009). Some pharmaceutical study results suggest that chitosan may help improve cholesterol levels when combined with a low-calorie diet (Ray, 2011; Sharecare, 2013).

\section{From crab shell waste to powder - infrastructure technology}

According to Nurhidajah and Yusuf (2009) the process of powdering crab shell waste requires several steps, including drying, milling and sieving. The first stage crab shell should be washed and blanched. Afterward, dried crab shell is then placed in a cabinet with a temperature of $70^{\circ} \mathrm{C}$ for 6 hours. The dried shells have to be downsized using a blender to obtain a smaller shell size, this process aims to further simplify the milling process using a steamroller, then the sifting is done using a sieve size of 60 mesh. It is then in the form of flour 
ready to be developed into other value-added products for supplemental food and feed.

In a larger scale (commercialization) what is needed is the technology transfer which can be adopted from the industrial processing of waste materials into useful substances. Key success of commercialization of an innovation product cannot be separated from the role of technology (Reisman, 1989; Rogers, 2003). Technology applicability is needed to not only include a grinding machine as main infrastructure but also to include the separation and extraction technology to discover substances required. Technology needs also cover (1) process residues for valuable materials (2) process chemistry to test product development (3) process packaging for final product, and (4) laboratory equipment for daily checks.

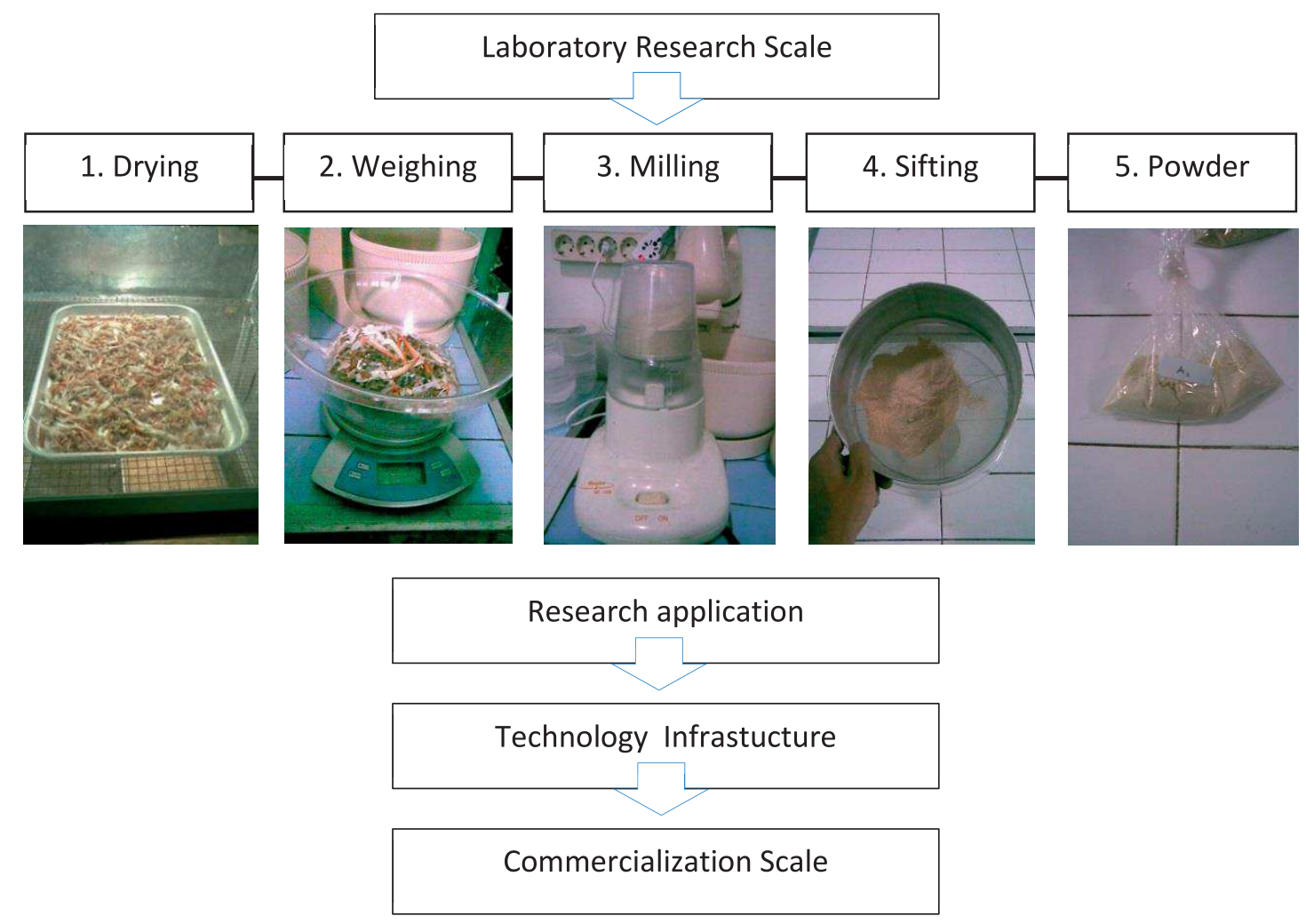

Figure 3. From laboratory-research to commercialization of crab shell waste

\section{Framework - planning and model of business}

In order to achieve the business success, there must be a good business plan and strategy as a guide to running and controlling the business ${ }^{11}$. Therefore, we need business plans of crab waste to evaluate the business project. The establishment of a crab shell powder factory in Indonesia is appropriate due to the availability of raw materials. In order to develop further crab shell

11 Business planning concept (Frinces, 2005; 2007) 
powder it is necessary to cooperate with an industry which requires such raw materials as powder shell especially in feed exporter countries e.g. European countries which have good prospects. In addition to the analysis of consumer needs, a marketing strategy involves the following questions:

- What are the benefits of crab shell powder as raw material for the food industries, the feed industries and the health industries?

- Why would someone want crab shell powder, what are the benefits?

- What is the uniqueness and specificity of crab shell powder products?

The intended target market includes (1) the salmon aquaculture industry (2) fish farms (3) the animal feed industry (4) industry food seasonings and flavor enhancer industries, (5) the pharmaceutical industry that produces supplements, and (6) the cosmetics industry. In order to reach this market target, the advantages and benefits of the product should be presented and promoted. Furthermore, it is necessary to learn the framework of actors, barriers, challenges and facilitators $(A / B / C / F)$ to this endeavor. Below is a detailed diagram to illustrate the position of the business:

Table 1. The $A / B / C / F$ chart of the crab shell waste business

\begin{tabular}{|c|c|c|c|c|c|}
\hline & Raw material & $\begin{array}{l}\text { Making the } \\
\text { powder }\end{array}$ & $\begin{array}{l}\text { Exporting to } \\
\text { Abroad }\end{array}$ & $\begin{array}{l}\text { Making final } \\
\text { product }\end{array}$ & $\begin{array}{l}\text { Selling the } \\
\text { product }\end{array}$ \\
\hline Actors & $\begin{array}{l}\text { Fishermen } \\
\text { Middlemen } \\
\text { Companies } \\
\text { Workforce }\end{array}$ & $\begin{array}{l}\text { Workforce } \\
\text { Supplement } \\
\text { Specialist }\end{array}$ & $\begin{array}{l}\text { Shipping } \\
\text { companies }\end{array}$ & $\begin{array}{l}\text { Workforce } \\
\text { Innovation } \\
\text { institutions } \\
\text { Laboratory }\end{array}$ & $\begin{array}{l}\text { Distributors, } \\
\text { shopping centre } \\
\text { and other stores }\end{array}$ \\
\hline Facilitators & $\begin{array}{l}\text { Entrepreneur } \\
\text { Network in the } \\
\text { crab industries } \\
\text { Local } \\
\text { Government }\end{array}$ & $\begin{array}{l}\text { Crab factory } \\
\text { Fishery and } \\
\text { organic } \\
\text { companies }\end{array}$ & $\begin{array}{l}\text { Agriculture } \\
\text { marketing } \\
\text { institution } \\
\text { Trade } \\
\text { Department }\end{array}$ & $\begin{array}{l}\text { Network } \\
\text { in exporter } \\
\text { country } \\
\text { Experts in } \\
\text { the required } \\
\text { technology }\end{array}$ & $\begin{array}{l}\text { Local network } \\
\text { exporter } \\
\text { country } \\
\text { Industries in } \\
\text { pharmaceutical, } \\
\text { spices, compost } \\
\text { and feed }\end{array}$ \\
\hline Challenges & $\begin{array}{l}\text { Investment } \\
\text { Acquiring the } \\
\text { material }\end{array}$ & $\begin{array}{l}\text { Acquiring } \\
\text { a small } \\
\text { factory/plant }\end{array}$ & $\begin{array}{l}\text { Storage } \\
\text { Quality } \\
\text { standard }\end{array}$ & $\begin{array}{l}\text { Collaborative } \\
\text { partnership } \\
\text { agreement }\end{array}$ & $\begin{array}{l}\text { Promotion and } \\
\text { awareness }\end{array}$ \\
\hline Barriers & $\begin{array}{l}\text { Seasonal effects } \\
\text { Human } \\
\text { resources } \\
\text { Collective } \\
\text { consciousness }\end{array}$ & $\begin{array}{l}\text { Technology } \\
\text { and } \\
\text { infrastructure }\end{array}$ & $\begin{array}{l}\text { Animal By- } \\
\text { products } \\
\text { Regulation } \\
\text { Export } \\
\text { procedures }\end{array}$ & $\begin{array}{l}\text { Capital and cost } \\
\text { production }\end{array}$ & $\begin{array}{l}\text { Tax } \\
\text { Substitute } \\
\text { products and } \\
\text { competitor }\end{array}$ \\
\hline
\end{tabular}

\section{Business Analysis and Commercialization Strategy}

Implementation of integrated business, starting with the planned location of crab shell powder industry can be established in Indonesia, considering the availability of sources of raw materials and other support resources. It is also necessary to determine whether specific product innovation can be 
harnessed from the waste crab after it has been exported to the country of destination. Further processing of shell powder requires cooperation with institutions abroad as an integrated business. Other important aspects that need to be considered, particularly for business developments, include: (1) principal activities such as logistics, operations, and sales (2) support activities which include procurement, technology development, and human resource management and business facilities. Routine monthly cost components include (1) the cost of procurement of raw materials, (2) supporting materials, (3) transportation, (3) labor, (4) processing operations, (5) packaging and (6) marketing. In order to gain a competitive advantage it is necessary to prepare a new way to coordinate all activities, new procedures and technologies to empower new or different inputs.

Business description: This section describes the idea of a business plan relating to products based on crab shell waste raw materials. The main product is crab shell powder where a market share can be expected to be gained. This opportunity is indicated by a need for animal feed products, spice and material health supplements, which is still quite high. The market can be gained through open cooperation, creating publications which give adequate information and conducting an intensive publicity campaign. The reason for selecting this type of business is:

- In Indonesia, crab waste is a cheap raw material and has not yet been utilized optimally.

- There is a potential high price for the end products as supplements and flavor enhancers.

- Contributing to the environmental sustainability of fisheries.

- Potential innovation and technology is still open for product diversification.

Market analysis: The market analysis section describes the data and information needs of the market for by-products of organic waste, in particular the commercial products related to crab shells. Data and information that can be collected with respect to market size, the number of potential consumers for products as well as the rate of growth and the development related industries. Powders of crab shells are also being produced and sold in the EU and US as organic soil amendments or compost for gardeners ${ }^{12}$. In general, the high-end marketing for natural organic products is growing, and the bio-pesticides attribute is definitely an asset (Stewart and NoyesHull, 2010). In Europe and Scandinavia in particular, the potential market is still wide open due to the growth of fish farmers, the increasing number of industry feed and pharmaceutical industries. We should remember that the

12 Potential value of compost markets, see European Compost Network - ECN, and The US Composting Council - USSC.

Journal of Entrepreneurship Management and Innovation (JEMI), Volume 9, Issue 4, 2013: 101-122 
Atlantic salmon aquaculture industry has boomed ${ }^{13}$. Specifically, to review the market potential according to the organic waste product innovations that can be developed (Chapter: Development by-product from crab waste), the marketing overview is presented as below:

- Natural supplements: Europe is the largest region for herbal supplements and remedies, accounting for the largest share of the world market (GIA, 2013a). Asia-Pacific and Japan make up the other important markets for herbal supplements on a global basis (Ibid). As reported by GIA (2012) forecasting that the global market for chitin derivatives will reach $\$ 63$ billion, while the global chitosan market will reach more than $\$ 21$ billion by the year $2015^{14}$. Chitosan advantage, some reports stated, is more useful for biomedical applications and dehydrations of aqueous solutions than chitin, since it possesses both hydroxyl and amino groups, which can be easily innovated and modified (Cosgrove, 2010).

- Feed additives: Rising awareness of the benefits of animal feed additives among veterinarians, feed-millers and integrators is expected to contribute to market expansion (Frost and Sullivan, 2006). The global animal feed additives market is growing at a Compounded Annual Growth Rate (CAGR) of 3.8\% from 2011 to 2018 (TMR, 2012). As stated by the new market research report on Animal Feed Additives, in Asia Pacific region led by China is represents the largest as well as the fastest growing market worldwide (GIA, 2013b). Growth in the area is led by increasing production as well as demand for such commodity.

- Spices materials: Spices come under commodity markets which are high in value (i.e. price) but low in volume (i.e. weight). Spices add flavor and a unique taste to the food, the food industry is ever growing with the spices (M\&M, 2013). Spice market key player countries in North America is US, in Asia are India, China, and Japan, and in Europe are UK, Germany, France, Spain, and Italy. India is the fastest growing market (Ibid). The key players for industry spice are e.g. Ajinomoto Co. in Japan, AVT McCormick Ingredients Ltd. in India, and B\&G Foods Inc. in US.

Competition and barriers: The business world is associated with competition and therefore needs to have a revolutionary product concept and be adaptive to change. Entrepreneurs need to always be aware that all businesses must have an idea or a fresh idea to produce a unique product and take full advantage. Competition will be focused on products that already exist in the current market, for example from kelp supplements and animal feed from

13 The report for salmon farming industry (Marineharvest, 2013). See also, recent development of aquaculture in Norway (NSC, 2013).

14 Global Strategic Business Report by Global Industry Analysts, Inc.

Knowledge, Participation and Waste Management - Selected Problems, A. Ujwary-Gil (Ed.) 
fish with low economic value. In addition, substitution products of shrimp and lobster shells powder will put pressure on this business.

In marketing side, there is a hard international market competition between producers of spices, feed additives and natural supplements. Countries such as India, Vietnam, Thailand and China are the main producers of spices and exporters to America, which is the largest consumer of spices by volume and value. The US accounts for $33 \%$ of the market, where western markets have a huge demand for spices products ( $M \& M, 2013)$. In production side, intense competition also occurs among suppliers of crab powder, due to the fact that well-established industries already have raw material suppliers that offer good quality.

In accordance to the US and EU ban on the use of antibiotics as growth promoters, organic products, i.e. organic feed additives, organic compost, herbal supplements are expected to emerge as suitable alternatives, offering significant growth potential, mainly in countries (e.g. China, Indonesia and India) with large volumes of feed and food exports to the US and EU countries. However, the organic waste industry was subject to additional regulatory burden and potential for impact upon the market restriction through Animal By-products Regulation or Good Industry Practice requirements.

Business strategy: The right strategy will attract consumers to buy products and encourage them to open cooperation. Managers need to promote their businesses through a number of marketing methods to explain the quality of the product. It is important that health benefits are included in disseminated information, and this can improve the marketing concept. The results of research into the content of calcium and protein in crab shells can also help promote this product.

There are a number of unique market-based circumstances that affect the organics industry, including regulations, geography, climate, structure of organics market and the progression of resource recovery initiatives (Meinhardt, 1999). In order to develop an international market development strategy for the organic waste industry, it is necessary to examine the nature market in each of target countries. The business strategy for crab shell powder may use Tyler's concept (1996), the main priority is that by-products that are considered to be high value markets tend to be developed first, the second priority is that by-products with lower value high volume markets can be developed thereafter.

\section{Building team and networks}

A team is a group organized to work together to accomplish a set of objectives that cannot be achieved effectively by individuals (Parcon, 2007). Building a team involves a process of selecting, developing, and training a working 
group in order to successfully achieve common goals. It includes motivating members to be responsible for carrying out group tasks. Team building should meet the demands of the task, quality work and timely results. Through cooperation and sharing knowledge and skills, a team is often able to complete tasks more effectively than an individual.

The team built for this business involves the element of managers, specialists and technicians. Managers have a responsibility to sustainability and business operations ranging from procurement of raw shell material, marketing and evaluation performance effectiveness. Expertise for the development of this team is required from various disciplines. Employees needed in the early stages include technicians to take care of crab waste material collection, its processing into powder and packing. A chemical engineering expert and a healthcare product quality expert will be required as well. Chemical technicians will be needed to run waste treatment techniques, and a quality expert will be required to guarantee the quality the final product when it is ready to be sold and consumed.

\section{Challenges and business implication in global perspective}

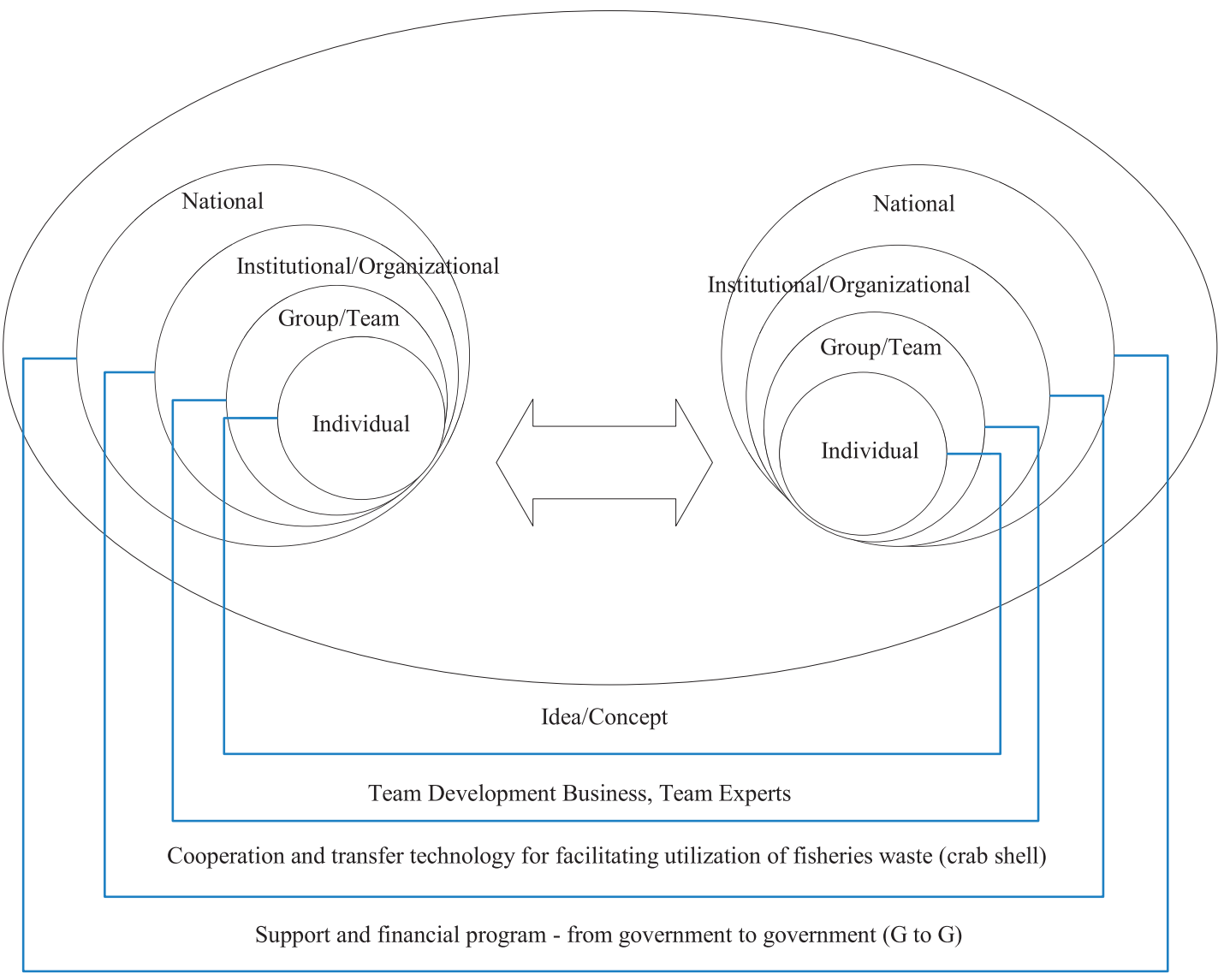

Figure 4. Development link of fisheries waste business Source: Adapted from Gibson (2008). 
The global perspective of the blue economy concept ${ }^{15}$ in fisheries sector becomes a driving force for business from waste materials. Solving problems often depends on how to look at the issues. This also applies to the problem of waste ${ }^{16}$. There are many perspectives on waste, whether it is the perspective of industry, environmentalists, community, and government. In turn, the perspective of the waste will cause a reaction to look as a potential. Management of zero waste in industry is a philosophy rather than a process or technology but it certainly can be considered an innovation for business (Capel, 2013). Implementing zero waste concepts in fisheries industry will eliminate all discharges to land, water or air that constitute a threat to many aspects primarily for human health.

The advantages of turning crab shell waste into beneficial products include; availability, low cost and high biocompatibility (Dorris, 2000). Business activities that take advantage of the waste associated with fishery conservation efforts include the interests of society and the primary industrial fishery sector. In order to provide support for this effort, therefore, it continues to be part of a system in the long-term problem solving for the stakeholders to be evaluated and analyzed. These businesses have a positive impact on globalization, especially for; (1) product development innovation opportunities (2) open cooperation among countries and among institutions who are interested (3) in supporting environmental conservation programs and fisheries development programs.

\section{Conclusion}

This research produces two important contributions including; (1) a theoretical review of creativity in encouraging new entrepreneurship, and (2) a business proposal for solving environmental problems through new ways of seeing the potential material to be a product worth selling. Business development based on the potential of organic waste in Indonesia provides new challenges for businessmen where the abundance of raw materials becomes an opportunity, in other hand lack of mutual awareness on environmental recovery becomes a weakness. Technology transfer and commercialization process of scientific research needs to be done in accordance with the motivation "from science to business". In this process, the active role of government to facilitate it and institutions of scientific and research to transfer their research results is needed.

For business perspective; The results of this research can be summarized as follows: (1) crab shell waste business development opportunities with

15 Paradigm to streamline fisheries resources without waste, See http://blueeconomyindonesia.com/. 16 Perspective "waste as a problem" or "waste as a potential". 
value added has a promising market (2) there are constraints and the lack of technological supporting, it should be addressed through cooperation with related industries and the governments (3) the strategy of increasing market access can be carried out by mapping market potential, increased networking, partnership development, and strengthening inter-business links.

For theory perspective; New patterns of competition between the entrepreneurs in the world contribute to providing the enriched and philosophical meaning of entrepreneurship today. The concept of turning garbage into gold is a simple thought, but it may mean that literally; waste can be taken for free while gold is highly precious. It is a new way of thinking entrepreneurs where opportunities can be done by acting creatively to change from no value to high price.

\section{Acknowledgment}

The author is grateful to Lene Foss, David V. Gibson and Colette Henry for constructive comments and valuable suggestions. The author also wishes to thank the Indonesian crab producers and their management member who spent time and shared information related this research.

\section{References}

Baldacchino, L. (2009). Entrepreneurial creativity and innovation. First International Conference on Strategic Innovation and Future Creation, Floriana - Malta. Retrieved from http://www. strategicfutures.eu/_data/assets/pdf_file/0011/87599/leonie baldacchino_paper_entrepreneurial_creativity_innovation.pdf. Accessed 27 May 2013.

Barringer, B.R., Ireland, R.D. (2006). Entrepreneurship: Successfully launching new ventures. New Jersey: Pearson Prentice Hall.

Capel, C. (2013) Innovations in waste. Waste Management World, Retrieved from: http://www.waste-managementworld.com/articles/print/volume-11/issue-2/features/ innovations-in-waste.html Accessed 2 October 2013

Caldecott, J., Indrawan, M., Rinne P., Halonen, M. (2011). Indonesia-Norway REDD+ Partnership: First evaluation of deliverables. Gaia Consulting Ltd. Final Report 3 May 2011.

Cosgrove, J. (2010). The Global Chitosan Market: Increasing application prospects are contributing to a continued positive outlook. Nutraceuticals World, Edition 2 December 2010.

Dorris, K. (2000). Removal of Heavy Metals from Wastewater Using Crab shells, Lamar University. Beaumont: Texas.

Drucker, P.F. (1985). The practice of entrepreneurship, innovation and entrepreneurship practice and principles. New York: Harper \& Row. 
FAO (2013). Waste management of fish and fish products. Fisheries and Aquaculture Department. Food and Agriculture Organization.

Fenoaltea, S. (1976). Real value added and the measurement of industrial production. Annals of Economic and Social Measurement, 5(1), 111-137.

Frinces, Z.H. (2005). Entrepreneurship and Business Innovation. Yogyakarta: Darussalam.

Frinces, Z.H. (2007). Business Planning Concept and Implementation. Yogyakarta: Mida Library.

Frost J., Sullivan P. (2006). Southeast Asian Animal Feed Additives Markets. Taylors Lane, Dublin: Research and Markets.

Foss, L., lakovleva, T., Kickul, J., Oftedal, E.M., Solheim, A. (2011). Taking innovations to market: The role of strategic choice and the evolution of dynamic capabilities. International Journal of Entrepreneurship and Innovation, 12(2), 105-116.

Fuduric, N. (2008). The Sources of Entrepreneurial Opportunities: Individuals and the Environment. PhD Dissertation. Aalborg University, Denmark.

GIA (2012). Chitin and Chitosan - Global Strategic Business Report. San Jose, CA: Global Industry Analysts, Inc.

GIA (2013a). Herbal Supplements and Remedies - Global Strategic Business Report. San Jose, CA: Global Industry Analysts, Inc.

GIA (2013b). Animal Feed Additives - Global Strategic Business Report. San Jose, CA: Global Industry Analysts, Inc.

Gibson, D. (2008). Commercial feasibility and the importance of markets. The University of Texas at Austin.

Gibson, D., Smilor, R. (1991). Key variables in technology transfer: A fieldstudy based empirical analysis. Journal of Engineering and Technology Management, 8(3-4), 287-312.

Henry, C. (Ed.). (2007). Entrepreneurship in the creative industries: An international perspective. Cheltenham: Edward Elgar.

Humphreys, P., Mcadam, R., Leckey, J. (2005). Longitudinal evaluation of innovation implementation in SMEs. European Journal of Innovation Management, 8(3), 283-304.

Jaworski, B.J., Kohli A.K. (1993). Market orientation: Antecedents and consequences. Journal of Marketing, 57(3), 53-70.

Li, T., Calantone, R.J. (1998). The impact of market knowledge competence on new product advantage: conceptualization and empirical examination. Journal of Marketing, 62(4), 13-29.

Lumpkin, G.T., Dess, G.G. (1996). Clarifying the entrepreneurial orientation construct and linking it to performance. Academy of Management Review, 21(1), 135-172.

Lumpkin, G.T., Dess, G.G. (2001). Linking two dimensions of entrepreneurial orientation to find performance: The moderating role of environment and industry life cycle. Journal of Business Venturing, 16(5), 429-445. 
Marineharvest (2013). Salmon Farming Industry Handbook 2013. Marine Harvest. Bergen, Norway.

Meinhardt (1999). Organics Market Development Strategy. Canberra: Environment Australia.

Melkers, J.E., Bugler, D., Bozeman, B. (1993). Technology transfer and economic development. In: Bingham R., and Meir, R. ed. Theories of Local Economic Development. New York: Sage Publications.

Meredith, G., Nelson, R., Neck, P. (1996). The Practice of Entrepreneurship. Lagos: University of Lagos Press.

M\&M (2013). Global Spices Market by Type, Applications and Geography: Trends and Forecasts (2011-2016). Pune: Markets \& Markets.

Molina-Castillo, F-J., Munuera-Aleman J-L. (2009). The joint impact of quality and innovativeness on short-term new product performance. Industrial Marketing Management, 38(8), 984-993.

Narver, J.C., Slater, S.F. (1990). The effect of a market orientation on business profitability. Journal of Marketing, 54(4), 20-35.

Nikijuluw, V. (2012). Mapping of market opportunities in Indonesia for Norwegian suppliers of sustainable marine solutions: Technologies and services for fisheries and aquaculture. A report prepared for Innovation Norway, November 2012.

NSC (2013). Aquaculture in Norway. The Norwegian Seafood Council. Troms $\varnothing$, Norway.

Nurhidajah, Yusuf, M. (2009). Analysis of protein, calcium and acceptance of flour from crab waste. National Seminar Proceedings, University of Muhammadiyah Semarang.

Nutralegacy (2009). Important Health Benefits of Crab Shell Extract. Nutra Legacy, Edition 10 November 2009.

Nystrom, H. (1993). Creativity and Entrepreneurship. Creativity and Innovation Management, 2(4), $237-242$.

Okpara, F.O. (2007). The value of creativity and innovation in entrepreneurship. Journal of Asia Entrepreneurship and Sustainability, 3(2), 1-14.

Parcon, P. (2007). Develop Your Team Building Skills. New Delhi: Lotus Press.

Pyle L.S. (2010). How to Do Market Research - The Basics. Entrepreneur, Edition 23 September 2010.

Reisman, A. (1989). Technology transfer: A taxonomic view. Journal of Technology Transfer, 14(3-4), 31-36.

Rogers, E.T. (2003). Diffusion of Innovations. Fifth edition. New York: Free Press.

Ray, S.D. (2011). Potential aspects of chitosan as pharmaceutical excipient. Acta Poloniae Pharmaceutica-Drug Research, 68(5), 619-622.

Shane, S. (2003). A General Theory of Entrepreneurship. Cheltenham: Edward Elgar. 
Sharecare (2013). Herbal supplements - What are chitosan supplements? Retrievedfrom:http://www.sharecare.com/health/herbal-supplements/ what-is-chitosan accessed 13 October 2013.

Stewart, G., Noyes-Hull, G. (2010). Feasibility of Producing Value added Products from Snow Crab Processing Waste in Cape Breton, Nova Scotia. The Gulf Aquarium and Marine Station Cooperative, Nova Scotia.

Sustainablefish (2013). Indonesian blue swimming crab fishery improvement project. Retrieved from: http://www.sustainablefish.org/fisheriesimprovement/crabs/ indonesian-blue-swimming-crab. Accessed 25 May 2013.

Tyler, R.W. (1996). Winning the Organics Game: The Compost Marketer's Handbook. Alexandria, Virginia: ASHS Press.

TMR (2012). Animal Feed and Feed Additives Market - Global Industry Size, Market Share, Trends, Analysis, and Forecast 2011 - 2018. Albany NY: Transparency Market Research.

Weerawardena, J. (2003). Exploring the role of market learning capability in competitive strategy. European Journal of Marketing, 37(3-4), 407-429.

Witt, P. (2004). Entrepreneurs' networks and the success of start-ups. Entrepreneurship and Regional Development, 16(5), $391-412$.

Wycoff, J. (1991). Mindmapping: Your Personal Guide to Exploring Creativity and Problem Solving. New York: The Berkley Publishing Group.

Yulianto, T. (2008). Ketika si capit biru terjepit krisis. Inspirasi Agribisnis Indonesia - AGRINA, Edition 10 November 2008. Retrieved from http://www.agrina-online.com/show_article.php?rid=10\&aid=1569 Accessed 25 May 2013

Zimmerer, T.W., Scarborough, N.M. (1996). Entrepreneurship and New Venture Formation. Upper Saddle River, New Jersey: Prentice Hall International. 


\begin{abstract}
Abstrakt (in Polish)
Niniejszy artykuł omawia wpływ kreatywności i innowacji na tworzenie możliwości dla przedsiębiorców zajmujqcych się przetwarzaniem odpadków na wartościowe zasoby. W dzisiejszych czasach, aby stworzyć nowy biznes konieczna jest znajomość procesu myślowego i planowania w przedsiębiorczości. Jedno z błyskotliwych powiedzeń o przedsiębiorcach mówi, że sq to osoby, które potrafiq "zamienić śmieci na złoto". Koncepcja ta opisuje ważnq cechę przedsiębiorców, którzy dostrzegajq i przewidujq możliwości biznesowe, a także dysponujq inteligencjq pozwalajqcq im na zamianę śmieci na gotówkę. Oznacza to, ze posiadajq oni odpowiednie zdolności do tworzenia innowacji oraz produktów o wartości dodanej, które można następnie sprzedawać. Analizowany przypadek dotyczy innowacyjnego wykorzystania odpadów przemysłu rybołówstwa ze szczególnym uwzględnieniem połowów kraba w Indonezji. Niniejszy artykuł przedstawia empiryczne perspektywy obejmujace (1) potencjalny biznes oparty na odpadach z pancerzy krabów, (2) technologie innowacyjnego wykorzystania pancerzy w celu stworzenia produktów o wartości dodanej oraz (3) analizę i komercjalizację. Wreszcie, przedstawiamy koncepcję nowego biznesu łączq̨c teorie przedsiębiorczej innowacji oraz transferu technologii w celu uzyskania równowagi ze środowiskiem naturalnym.
\end{abstract}

Słowa kluczowe: nowa przedsiębiorczość, innowacja i kreatywność, Indonezja, odpady z produkcji rybołówstwa, proszek z pancerzy krabów. 